肝細胞癌に対する術前肝動脈塞栓術併用肝切除術の検討

\author{
福岡大学第 1 外科（主任：志村秀彦教授） \\ 片 岡 厚生五十君 裕 玄 志村秀 彦 \\ 同 放射線科 \\ 岡 崎 正 敏
}

肝細胞癌の術前 TAE 併用肝切除65症例について, 術前 TAE の功罪並びに予後に影

響を及ぼす因子を検討した. Lipiodol-TAE 像のCT 後により高率 (9.2\%) に微小娘結 節が発見された。これが術前 TAEの最大の利点と思われた。 また, 術前 TAE の臨床検 查值に及ぼす影響を検討し，フルブミン，コリンエステラーゼ, プロトロンビン時間が 著明に低下した。術前 TAE 併用肝切除例の予後を左右すると思われる関連因子14項目 を選び, 有意差検定を行ったが, 顕微鏡的門脈腫掦塞栓の有無, 手術根治度, 術中出血 量の 3 項目のみに有意差を認めた。クラスター分析による多数量解析では影微鏡的門脈 腫場塞栓がなく, 腫湯径 $30 \mathrm{~mm}$ 以下の単発病変㧊よび多発病変でも単葉に存在する. 65 歳以下の症例は術前 TAE 併用肝切除で 5 年生存する可能性が $50 \%$ 以上であった。

真引用語: 肝細胞癌, 術前 TAE 併用肝切除術, 術後生存率, 肝細胞癌の予後因子, 多変量解 析 (クラスター分析)

\section{緒 言}

近年, 肝細胞癌 (hepatocellular carcinoma, 以下 HCC) に対する積極的治療法として肝切除術"), 肝動脈 塞栓術 ${ }^{899}$ (transcatheter arterial embolization, 以下 $\mathrm{TAE})$, 畽漡内アルコール注入療法10)等が行われてい るが, 現在のところ, HCC の根治的治療法としては肝 切除術が最良と考えられる(7)13)。しかしながら，肝切 除療法による 5 年生存率は全国集計22 $28.5 \%$ といまだ 满足な治療成績は得られていない。

癌の根治手術に際し, 最も留意すべきことは胃癌, 大腸癌等で通常いわれているようなnon touch isolation ${ }^{3)}$ である. 同法は癌細胞の散布を防止するた めに腫瘍摘出前に予め流出入脈管遮断を行ら方法であ るが, HCCに対する肝切除ではせいぜい肝門部処理が 行われているにすぎない. Non touch isolation を試み るにしても解剖学的関係から肝では流入流出経路を完 全に遮断することは不可能である.

これらの対応策として，肝切除を行ら前に TAEを 行い, 睡晧内の viable cell を減少させ, 手術操作によ る癌組織の術中散布を防止しょらとする試みがなされ

1991年 4 月 9 日受付 1991 年 7 月 3 日採用
ている4. しかしながら, TAE 後の残肝予備能の低下 などの合併症を考虑してか，この術前 TAE 法を取り 入れている施設は少ないようであり年)，訹前 TAE 併 用肝切除術の功罪について詳細に解析した報告はほと んど認められない.そこで, 術前 TAE 併用肝切除術を 施行した HCC 65症例を対象に術前 TAE の功罪並び に予後を左右する因子について検討を行った。

\section{対象}

福岡大学病院肝診断治療グループ開設以来, 1982年 11 月から1989年 7 月までの 6 年 9 力月間に当院第 1 外 科に打いて TAE 後肝切除術を施行した HCC は69例 である. らち術死 4 例を除く65症例を対象とした。

年齢は17歳から71歳（平均年齢56.2歳）で，男性56 名, 女性 9 名である.

各症例に TAE 前および手術前に採血を行って臨床 検查値を求めた。

腫場占拠部位および腫場の大きさはそれぞれ，主畽 瘍の占拠部位, 切除標本での主腫瘍の最大割面の長径 として記載した。

症例はいずれも1990年 3 月31日現在, 術後 9 カ月以 上経過した症例である。

方法及び検討項目 
術前 TAE 法は Lipiodol (2 10ml) と抗癌剤の懸濁 液を固有肝動脈から全肝に流し，次に抗癌剤の水溶液 中に Spongel 混合末 $(1 / 2 \sim 2$ 個)を混入し，用手的に 擋拌し，癌の支配動脈に注入した。使用した抗癌剤の 種類及び量は症例により異なり, aclarubicin 単独 $10 \sim 40 \mathrm{mg}$, mitomycin $\mathrm{C}$ 単独 $10 \sim 40 \mathrm{mg}$, mitomycin C $10 \sim 20 \mathrm{mg}$ と doxorubicin 10〜20mg の併用などを 用いた。

対象とした65症例の肝切除術式は二区域以上の切除 8 例（左三区域切除 3 例，拡大右二区域切除 1 例，右 二区域切除 3 例, 中央二区域切除 1 (例), 区域切除 10 例 （拡大右前区域切除 1 例, 右前区域切除 2 例, 右後区域 切除 4 例, 左外側区域切除 3 例), 亜区域切除 28 例, 亜 区域以下の部分切除 2 例, 菙瘍核出術17例である.

\section{I. 術前 TAE の意義並ひに肝に及ぼす影響}

1. 術前 TAE 後 CT 像 (Lipiodol-CT) に上る微小 娘結節の検出。

2. 手術操作に上る癌散布防止効果の検討。（腫場壊 死率，再発率及び推定生存率)

3. 臨床検査值に及ぽす TAE の影響.

II. 予後に影響を及ほすす関連因子の解析と生存率

1. 全症例の推定生存率を Kaplan-Meier 法拉よび その95\%信頼区間を Bootstrap 法にて行った ${ }^{11)}$.

2. 関連因子14項目, 即ち, 年齢, 性, 庫場占拠部位, 非癌部肝組織型〔肝硬変 (以下 LC), 慢性活動性肝炎 (以下 CAH), 慢性非活動性肝炎 (以下 CIH)], Stage 分類 $\left[I \sim I V\right.$, 原発性肝癌取扱い規約 $\left.{ }^{25}\right]$ ], 肝内転移[以 下 IM] の有無, 頭微鏡的門脈内腫瘍塞栓（以下 vp） の有無, 被膜形成の有無, 主腫瘍内残存癌の有無, 肝 切離面に打ける癌浸潤（以下 $\mathrm{tw}$ ) の有無, 切除域, 手 術根治度, 術中出血量, 手術時間について KaplanMeier 法により推定生存率を検討した。有意差検定は Logrank 検定を用い，検定有意水準は0.05とした。

3.上記の関連因子14項目に主腫瘍の大きさを加兄， 15項目についてクラスター分析による多变量解析を 行った。予後に同時に影響を及ぽす要因を検討するた めに, Logrank 法により有意差の大きい順に検討し， クラスター1〜4とした. 分割基準に Logrank 統計量 を用いた回帰樹木法を適用した ${ }^{1226227)}$ 。なお，併合基準 （Logrank 統計量）に対する有意差は分割基準の場合 と同様に 0.05 とした。

\section{結果}

I. 術前 TAE の意義並びに肝に及ぼす影響

1. 術前 TAE 後, それまでの総合画像診断では指摘
できなかった微小娘結節が CT 像で65例中 6 例 （9.2\%）に新たに発見された（図 1 )。微小娘結節の腫 場径は $5 \mathrm{~mm} 2$ 例， $4 \mathrm{~mm} 2$ 例， $3 \mathrm{~mm} 2$ 例であった。

2. 手術操作による癌組織の術中散布を術前 TAE により，どの程度防止可能かどうかを検討するために 単発病変でかつ vp (-) の30症例について壊死率, 推 定非再発率（図 2) 及び推定生存率（図 3) を比較検

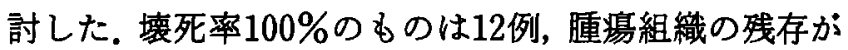
一部に認められたものは18例（壊死率 98 - 90\% 9 例, $80 \%$ 以下 9 例）であった。完全壊死症例の再発率は $33.3 \%$, 不完全罗死症例では $61.1 \%$ ，全症例で $50.0 \%$ であったが両者間に有意差は認められなかった。

Kaplan-Meier 法による推定生存率をみると, 前者 では 1 年生存率 ( 1 生率), 3 年生存率 ( 3 生率), 5

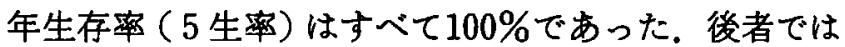
各々 $100 \%, 88.4 \%, 60.0 \%$ であったが有意差は認めら れなかった。

3. 術前 TAEの肝に及ぼす影響をみるため臨床検 查値を $\mathrm{TAE}$ 前と手術直前の値とで比較検討を行っ た. TAEの前後で有意差を認めた臨床検査値はアル ブミン, コリンェステラーゼ，プロトロンビン時間， GOT, GPT, 総ビリルビン, ZTT, $\boldsymbol{\gamma}$-クロブリンであっ た。 $\mathrm{t}$ 值でみるとアルブミン, コリンエステラーゼ, プ ロトロンビン時間が低下, ZTT, $\boldsymbol{\gamma}$-グロプリンが上昇,

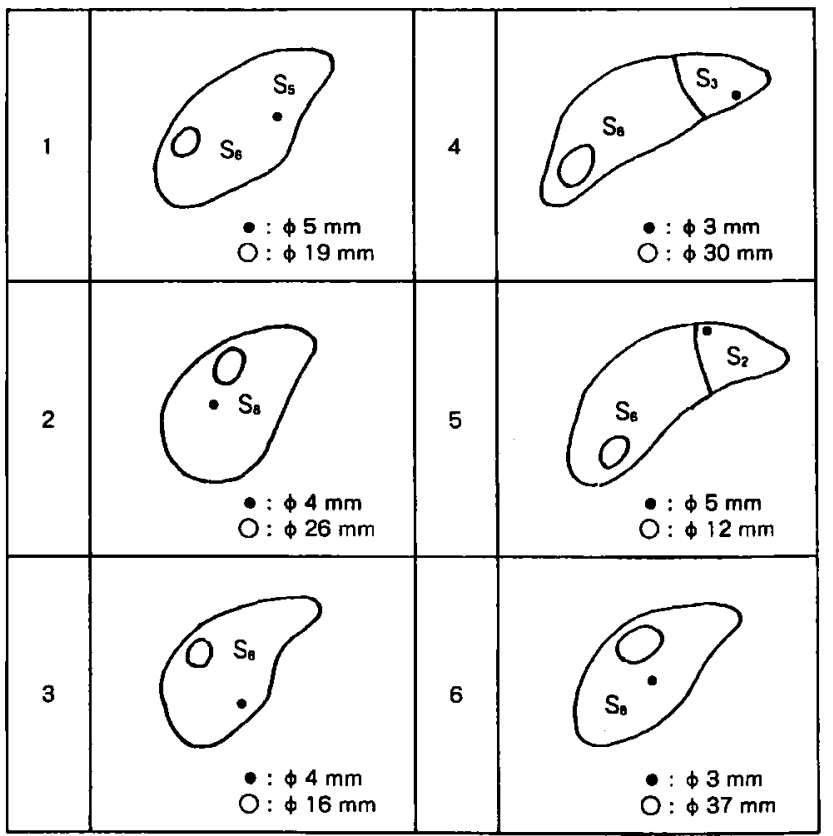

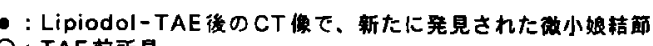
$O$ : TAE 前所見

図 1 Lipiodol-TAE 啳の CT 像で，新たに発見され た微小娘結節 


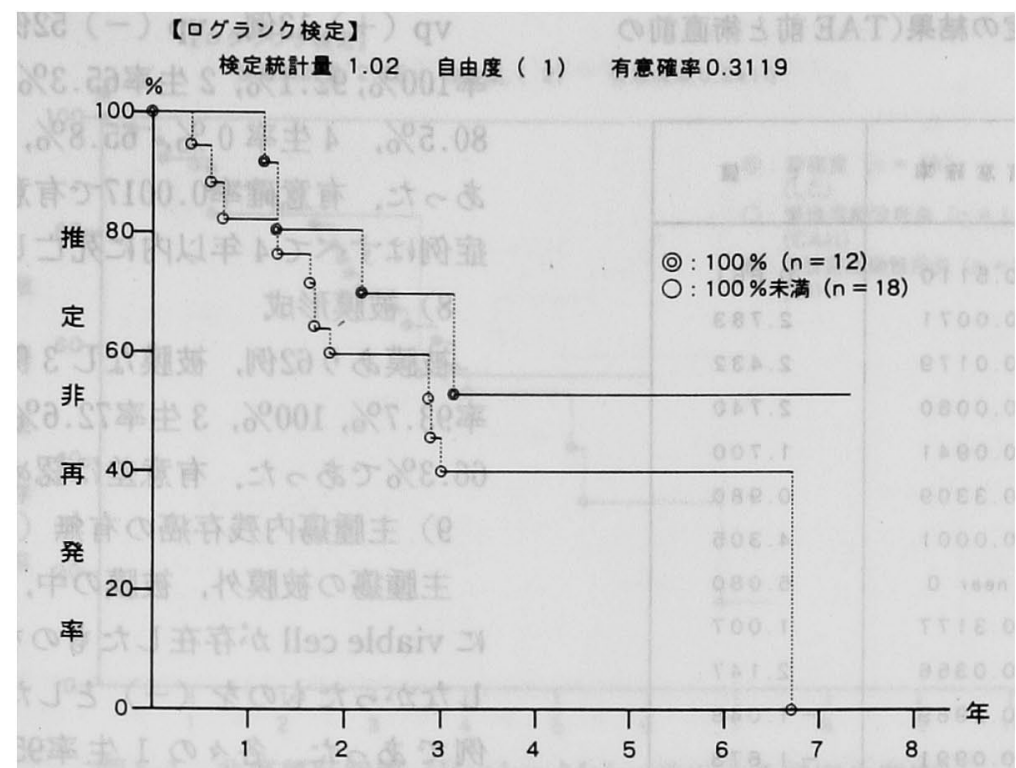

図 2 肝癌の壊死率と推定非再発率（Kaplan-Meier 法）

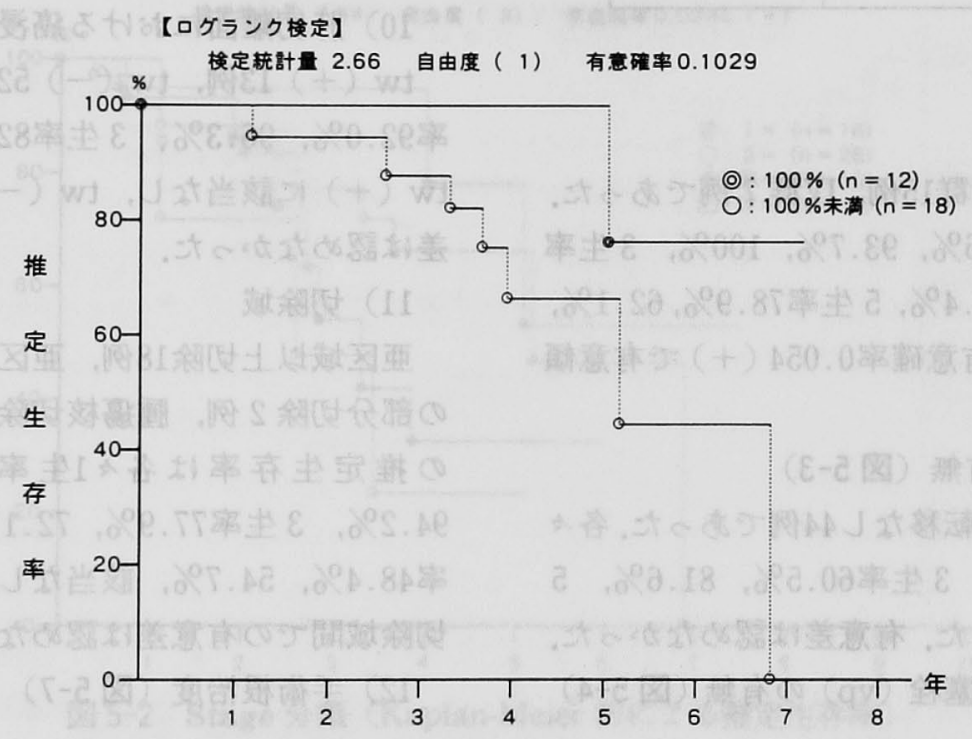

図 3 肝癌の偯死率と推定生存率 (Kaplan-Meier 法)

GOT，GPT，榕ビリルビンが改善していた（表 1).

II. 予後に影翌を及ほす関連因子の解析と生存率

1. 術前に TAEを施行した65症例の手術日からの 推定生存率は図 4 に示すごとく，5年生存率は $56.1 \%$ であった。

2. 予後に影響を及ぼすと考えられる関連因子14項 目について，個々に条件を設定し，検討した。

\section{1) 年齢}

年齢を65歳未満と65歳以上に分けて検討した。65歳 末満52例，65歳以上13例であった。 5 生率は各々

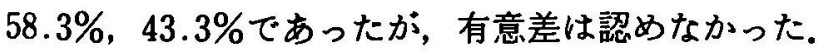

2）性
男性 56 例，女性 9 例で 5 生率は各々 $57.8 \% ， 52.2 \%$ と有意差は認めなかった。

3）腫瘍占拠部位

主腫瘍が右葉にあるかないかで分けて検討した，右 葉あり55例, 右葉なし10例であった。推定生存率は各々 1 生率 $94.2 \%, 90.5 \%, 3$ 生率 $76.8 \%, 57.9 \%, 5$ 生 率 $56.8 \% ， 57.9 \%$ で有意差は認めなかった。

4) 非癌部肝組織型（図 5-1）

LC 46例, CAH 14例, CIH 5 例であった. 各々の 1 生率 $93.7 \%, 91.6 \%, 100 \%, 3$ 生率 $70.0 \%, 83.2 \%$, $100 \% ， 5$ 生率 $42.2 \% ， 55.8 \% ， 100 \%$ であった，有意 差は認めなかった。 
表 1 臨床模查值の $\mathrm{t}$ 検定の結果(TAE 前之術直前の 比較)

\begin{tabular}{|c|c|c|c|}
\hline 項 & & 有意確率 & $\mathrm{t}$ 値 \\
\hline 稳タンバク & t & 0.5110 & 0.661 \\
\hline アルブミン & 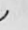 & 0.0071 & 2.783 \\
\hline コリンエステラーゼ & & 0.0179 & 2.432 \\
\hline プロトロンビン時間 & & 0.0080 & 2.740 \\
\hline トロンホテスト & & 0.0941 & 1.700 \\
\hline ヘバブラスチンテスト & & 0.3309 & 0.980 \\
\hline 0 & T & 0.0001 & 4.305 \\
\hline G & T & near 0 & 5.080 \\
\hline D & H & 0.3177 & 1.007 \\
\hline 総ビリルビ ン & 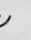 & 0.0356 & 2.147 \\
\hline $\begin{array}{lllll}I & C & G & I & 5\end{array}$ & . & 0.2989 & -1.048 \\
\hline $\begin{array}{ll}T & T\end{array}$ & T & 0.0991 & -1.673 \\
\hline z & T & 0.0002 & -3.974 \\
\hline 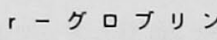 & 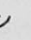 & near 0 & -4.811 \\
\hline
\end{tabular}

\section{5) Stage 分類（図 5-2）}

I 群18例，II群25例，III群15例，IV群 7 例であった。 各々の 1 生率 $94.7 \%, 91.6 \%, 93.7 \%, 100 \%, 3$ 生率 93.7\%, $76.8 \%, 52.1 \%, 47.4 \%, 5$ 生率 $78.9 \%, 62.1 \%$, $31.4 \%, 23.7 \%$ であり，有意確率0.054（+）で有意傾 向を示した。

6）肝内転移（IM）の有無（図 5-3）

肝内転移あり21例, 肝内転移なし44例であった。各々 の 1 生率95.3\%，93.2\%，3生率60.5\%，81.6\%，5 生率38.4\%, 66.8\%であった。有意差は認めなかった。

7) 湿微鏡的門脈内腫湯塞栓（vp）の有無（図 5-4） vp（+）13例, vp（一）52例であった．各々の 1 生 率100\%, 92.1\%, 2 生率 $65.3 \%, 87.9 \%, 3$ 生率 $32.6 \%$, $80.5 \%, 4$ 生率 $0 \%, 65.8 \%, 5$ 生率 $0 \%, 65.8 \%$ て あった，有意確率 $0.0017 て ゙$ 有意差を認めた。vp（十） 症例はすべて 4 年以内に死亡した.

8）被膜形成

被膜あり 62 例，被膜なし 3 例であった，各々の 1 生 率93.7\%, 100\%, 3 生率 $72.6 \%, 100 \%, 5$ 生率 $54.7 \%$, $66.3 \%$ であった。有意差は認めなかった。

9）主腫瘍内残存癌の有無（図 5-5）

主腫場の被膜外, 被膜の中, 被膜の内側のいずれか に viable cell が存在したものを(十)，いずれにも存在 しなかったものを（一）とした。（十）41例，（一) 24 例であった。各々の 1 生率 $95.3 \%, 91.6 \%, 3$ 生率 $65.8 \%, 84.7 \% ， 5$ 生率 $43.7 \% ， 76.8 \%$ であり，有意 確率0.064 と有意傾向を示した。

10）肝切離面に打ける癌浸潤（tw）の有無（図 5-6） $\mathrm{tw}(+)$ 13例, $\mathrm{tw}$ (一) 52例であった。各々の1生 率92.0\%，96.3\%、3 生率82.0\%，72.6\%，5生率は tw（十）に該当なし，tw（一）58.9\%であった，有意 差は認めなかった。

11）切除域

亜区域以上切除18例，亜区域切除28例，亜区域以下 の部分切除 2 例, 腫浧核切除17例であった，各切除域 の推定生存率は各々1生率100\%，89.5\%，100\%, $94.2 \%, 3$ 生率77.9\%, 72.1\%, 100\%，69.5\%，5生 率 $48.4 \% ， 54.7 \%$ ，該当なし，該当なしであった，各 切除域間での有意差は認めなかった。

12）手術根治度（図 5-7）

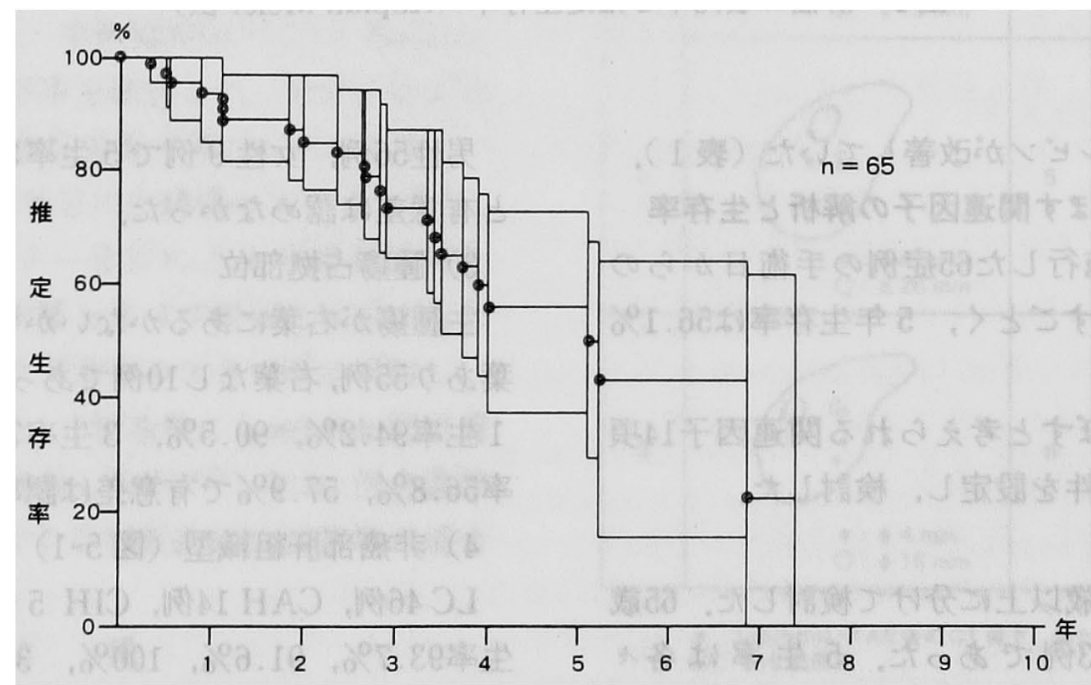

图 4 肝禹一TAE 手術例：Kaplan-Meier 法による推定生存率扰よびその95\%信頼 区間：Bootstrap 法 


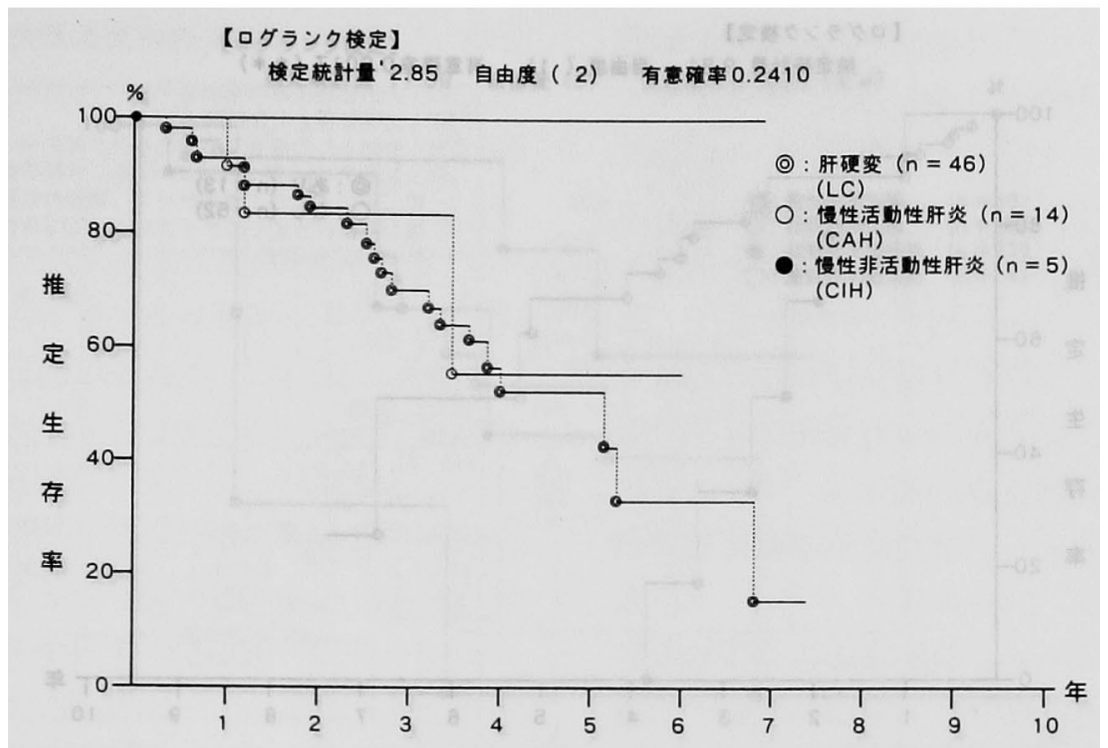

図 5-1＼cjkstart非癌部肝組織（Kaplan-Meier 法による推定生存率）

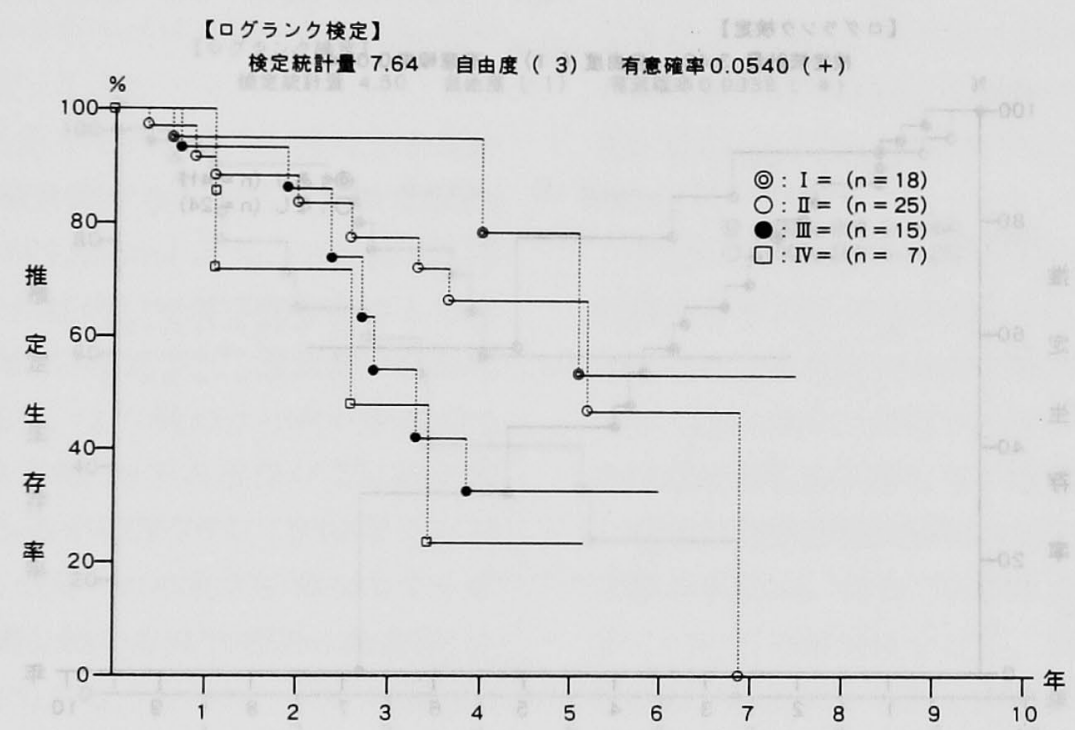

図 5-2 Stage 分類 (Kaplan-Meier 法による推定生存率)

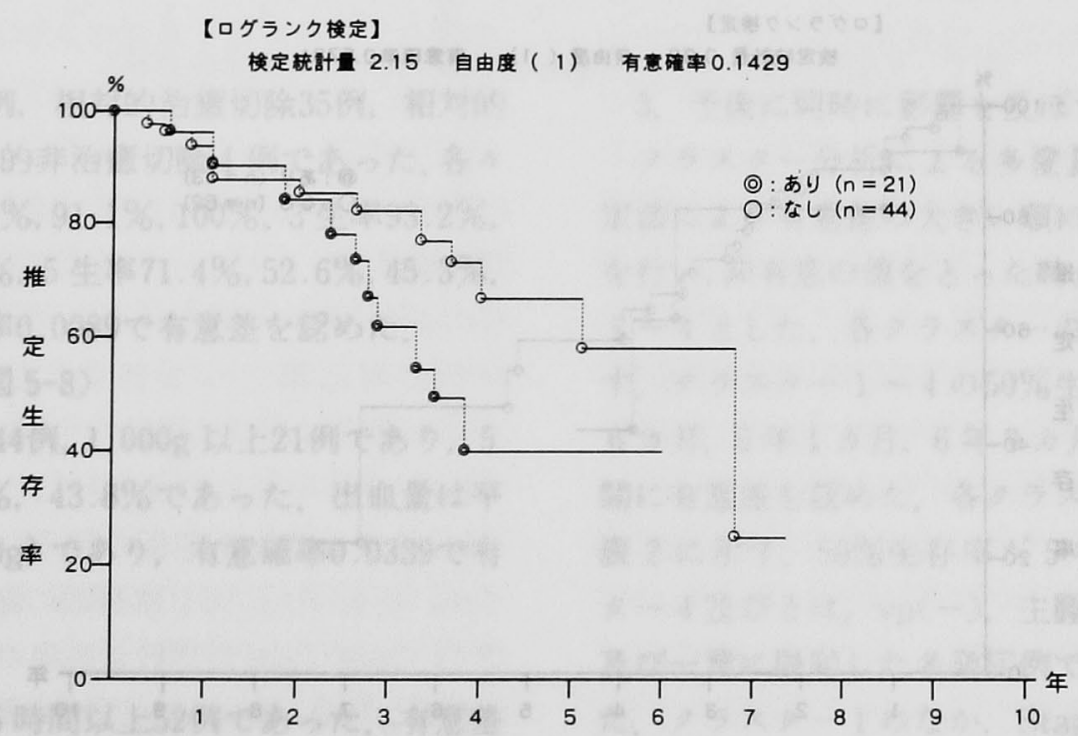

図 5-3 肝内転移（IM）の有無（Kaplan-Meier 法による推定生存率） 


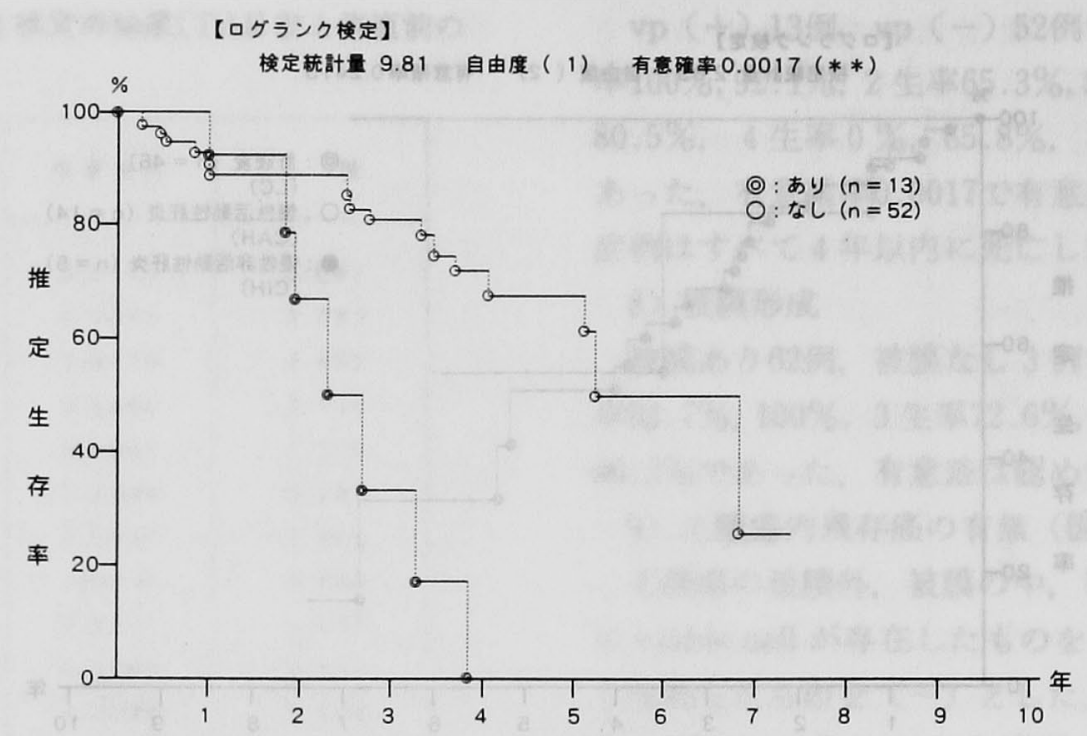

図 5-4 顕微鏡的門脈内腫瘍塞栓（vp）の有無（Kaplan-Meier 法による推定生存率）

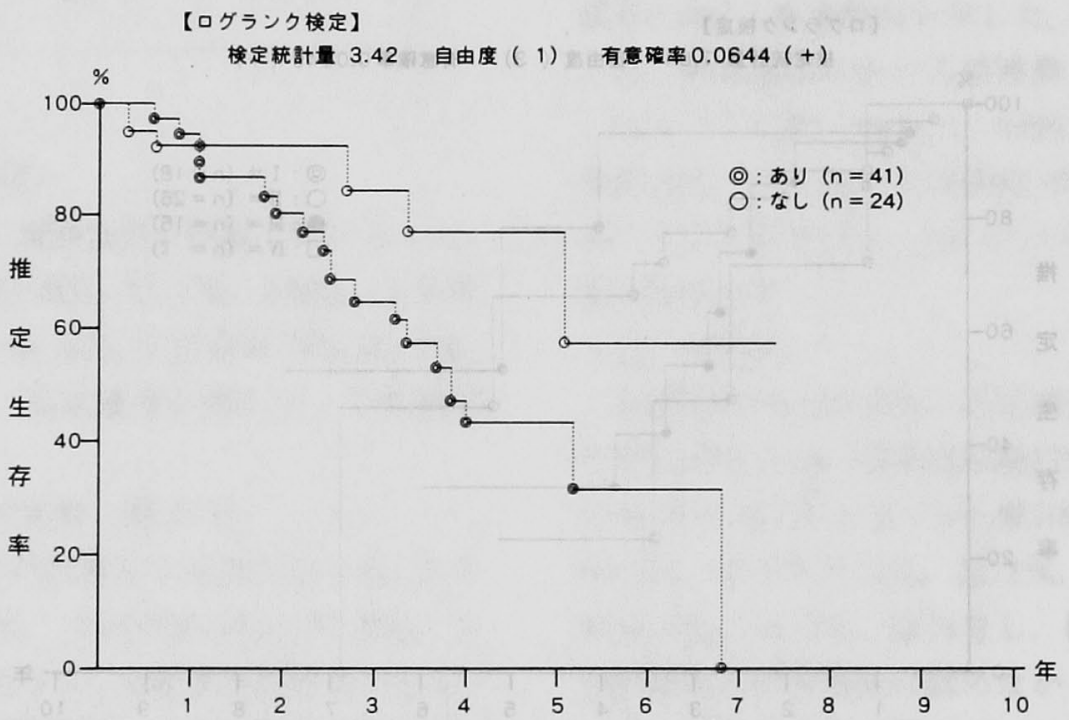

図 5-5 主腫瘍内残存癌の有無（Kaplan-Meier 法による推定生存率）

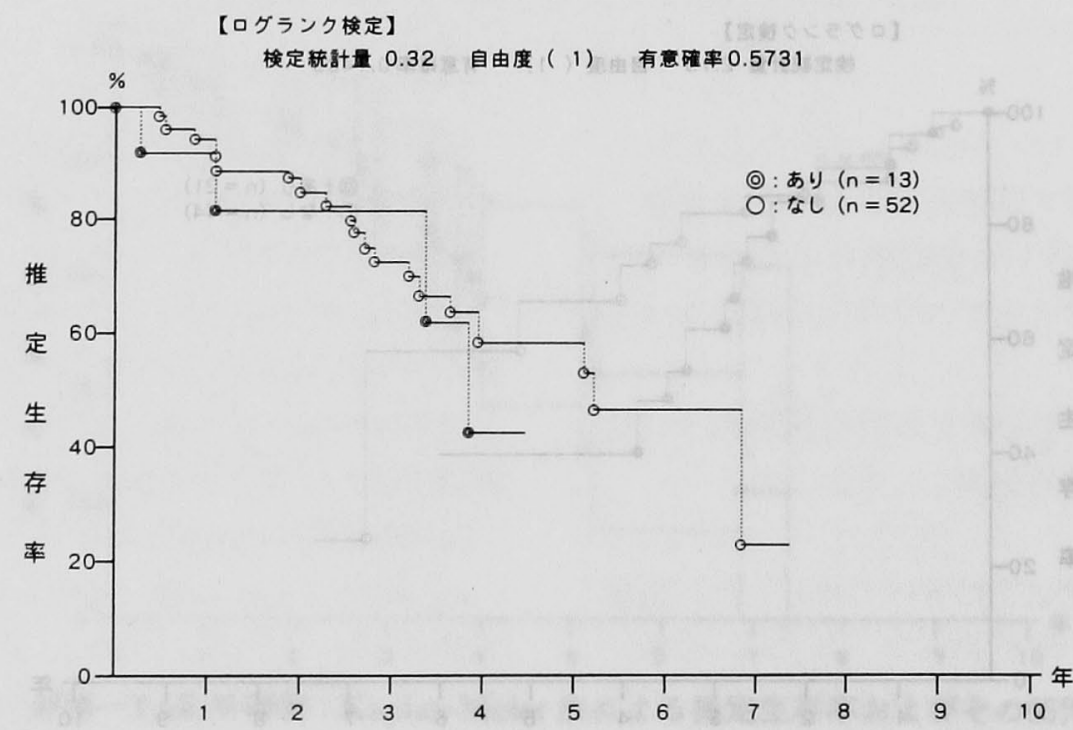

図 5-6 肝切離面の癌浸潤（tw）の有無（Kaplan-Meier 法による推定生存率） 


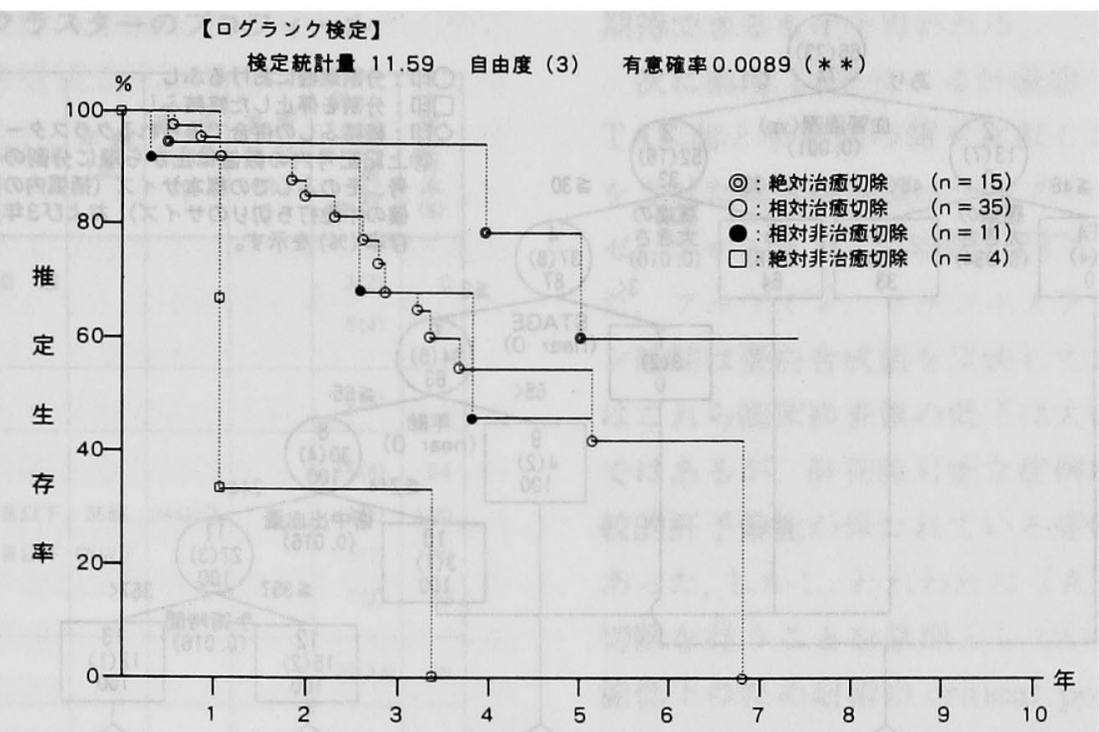

図 5-7 手術根治度（Kaplan-Meier 法による推定生存率）

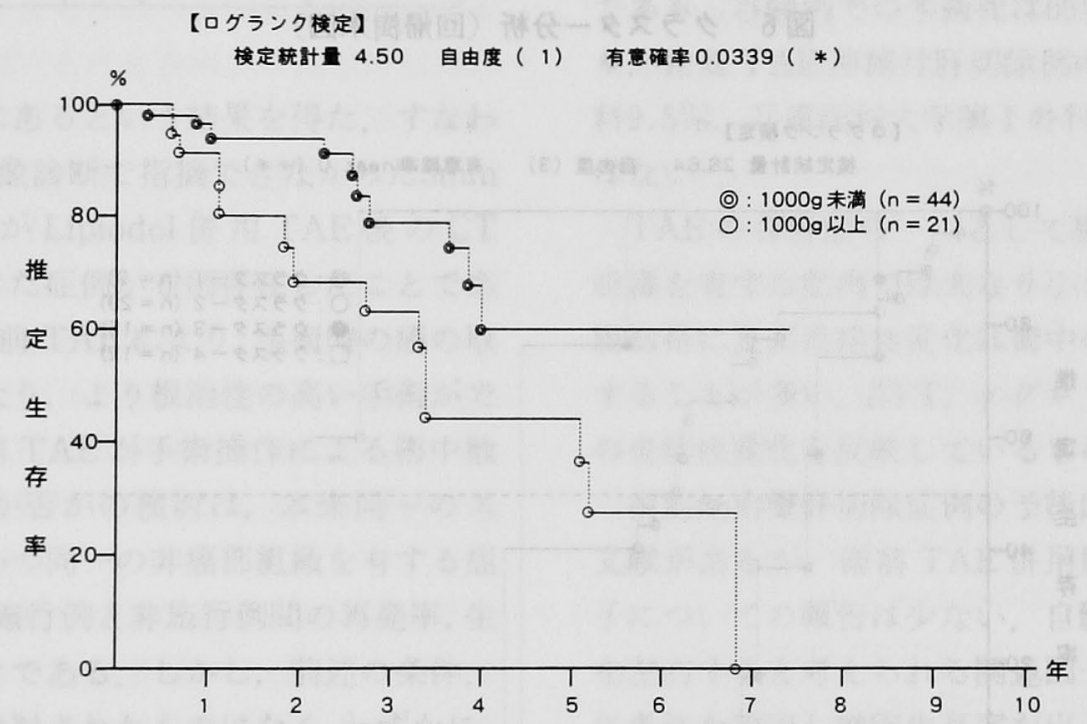

図 5-8 術中出血量（Kaplan-Meier 法による推定生存率）

絶対的治瘭切除15例，相対的治瘾切除35例，相対的 非治痹切除11例，絶対的非治复切除 4 例であった. 各々 の 1 生率 $93.2 \%, 94.2 \%, 91.1 \%, 100 \%, 3$ 生率 $93.2 \%$, $67.9 \%, 67.9 \%, 33.2 \%, 5$ 生率 $71.4 \%, 52.6 \%, 45.3 \%$, $0 \%$ \%あり，有意確率0.0089で有意差を認めた。

13）術中出血量（図 5-8）

出血量 $1,000 \mathrm{~g}$ 末満 44 例, $1,000 \mathrm{~g}$ 以上 21 例であり, 5 年生存率は各々 $60.8 \% ， 43.8 \%$ であった。出血量は平 均 $917.5 \mathrm{~g}(200 \sim 6,600 \mathrm{~g})$ であり，有意確率0.0339で有 意差を認めた。

14）手術時間

5 時間未満13例， 5 時間以上 52 例であった。有意差 は認めなかった。
3. 予後に同時に影響を及ぼす要因の検索

クラスター分析による多変量解析にて Logrank 検 定法により有意差の大きい順にクラスター分析(図 6) を行い,非有意の值をとった時点で終結し，クラスター 1〜4 とした。各クラスターの推定生存率を図 7に示 す.クラスター 1 - 4 の $50 \%$ 生存率は各々 2 年, 3 年 6 力月, 5 年 1 力月, 6 年 9 力月であり, 各クラスター 間に有意差を認めた。 各クラスターのプロフィールを 表 2 に示す. $50 \%$ 生存率が 5 年以上であったクラス ター 4 及び 3 は, $v p(-)$, 主連瘍径 $30 \mathrm{~mm}$ 以下の単発 及び一葉に限局した多発症例で65歳以下の症例であっ た.クラスター1のなか, Stage IV 症例は vp (一), 主腫瘍径 $30 \mathrm{~mm}$ 以下でも 3 年生存率 $0 \%$ であり, 又, 


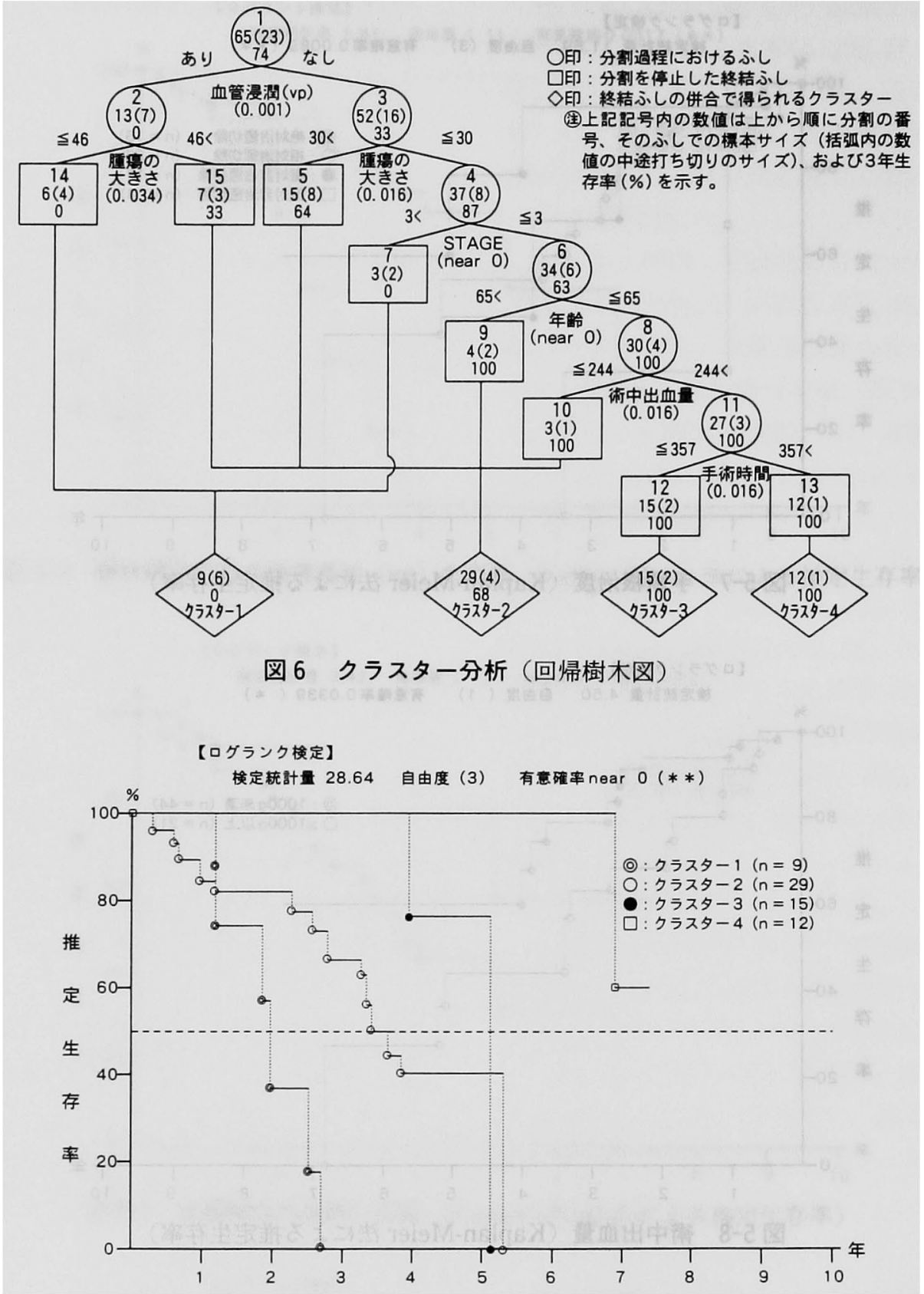

図 74 個のクラスター（Kaplan-Meier 法による推定生存率）

$\mathrm{vp}(+)$, 主腫湯径 $46 \mathrm{~mm}$ 以下の症例でも同様に 3 年生 存率 $0 \%$ であった。

\section{考案}

今回，われわれが行った術前 TAE 併用肝切除例65 症例の推定生存率は56.1\%と良好であったが，術後再 発が38例（58.5\%）と高率に認められている。

HCC 肝切除症例の主たる死亡原因は，いわゆる残肝 再発死亡である。 この残肝再発は，異時性の多中心性 発癌もしくは経門脈性肝内転移によるるのと考えられ

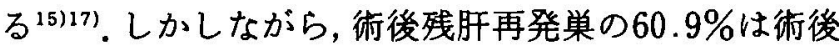
1 年末満に発見されたとの黒田らの報告16) あり，こ
れらのいわゆる残肝再発巣は術時すでに存在した微小 肝内転移巣, むしくは手術操作による術中経門脈性散 布によるむのの可能性む極めて高いと考えられた。 こ れらの対応策として術前 TAEに chemoembolizationを導入したのは岡村らかであり，その後諸施設で あ同法が試みられてきだ199.しかしながら，術前 TAEによる残肝予備能の低下などの合併症を考虑し てか, 術前 TAE 法を積極的に導入している施設は少 なく, 術前 TAE 併用肝切除術の功罪について詳細に 解析した報告はほとんど認められない。

自験例65例での検討では, 術前 TAEの最大の利点 
表 24 個のクラスターのプロフィール

\begin{tabular}{|c|c|c|c|c|c|c|c|c|c|}
\hline $\begin{array}{l}n \\
5 \\
x \\
y \\
1\end{array}$ & L & 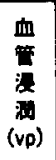 & $\begin{array}{c}\text { 主腱の } \\
\text { 大きさ } \\
(\mathrm{mm})\end{array}$ & STAGE & 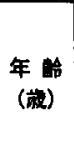 & $\begin{array}{c}\text { 中 } \\
\text { 出血量 } \\
\text { (g) }\end{array}$ & 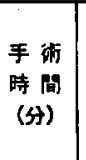 & 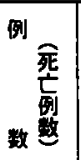 & 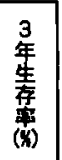 \\
\hline & 7 & なし & 30LAT & III 超 & & & & $3(2)$ & \\
\hline 1 & 14 & あり & 46L厂 & & & & & $6(4)$ & 0 \\
\hline & it & & & & & & & $9(6)$ & \\
\hline \multirow{5}{*}{2} & 5 & なL & 3018 & & & & & $15(8)$ & 64 \\
\hline & 9 & なL & 30L下 & III以下 & 65趣 & 244LT & & $4(2)$ & 100 \\
\hline & 10 & なし & 30以下 & III 以下 & 65以下 & & & $3(1)$ & 100 \\
\hline & 15 & あり & 46以上 & & & & & $7(3)$ & 33 \\
\hline & it & & & & & & & $29(14)$ & 68 \\
\hline 3 & 12 & IL & 30L下 & III & 65以下 & 244题 & 357以下 & $15(2)$ & 100 \\
\hline 4 & 13 & なL & 30以下 & UL上下 & 65以下 & 244超 & 357数 & $12(1)$ & 100 \\
\hline
\end{tabular}

は微小娘結節の発見にあるといら結果を得た。すなわ ち, TAE 前の総合画像診断で指摘できなかった $5 \mathrm{~mm}$ 以下の钽小娘結節が Lipiodol 併用 TAE 後のCT 像20)で新たに発見できた症例か６例存在したことであ る。これらの症例は術前 TAEにより，手術時の癌の取 り残しが防止可能となり，より根治性の高い手術がで きたことになる。術前 TAEが手術操作による術中散 布を防止可能であるか否かの検討は，本来同一のス テーシで同一術式，かつ同一の非癌部組織を有する症 例を用い, 術前 TAE 施行例と非施行例間の再発率, 生 存率の比較を行うべきである. しかし，前述の条件. 十分に満たした上で検討されたものはなく，わずかに， 術前 TAE 施行例と非施行例間に生存率の比較がなさ れたるのが散見されるのみであり，現在のところ両者 間に有意の差はないとされている6). 著者らは, vp(-) で単発病変の症例に術前 TAEを施行し, 腫湯が完全 壊死に陷った症例と非完全壊死症例について再発率拉 よび生存率の比較検討を行った。しかし，両者間に有 意差はなく，術前 TAEが手術操作による術中散布の 防止効果の確証を得ることはできなかった。完全壊死 症例のなか再発した 4 例はすべて, 術後 1 年以上経過 して再発したすのであり，また再発部位は切除時の腫 瘍占拠部位とは異なる他の区域に存在していたので， これらの病変は多中心性発癌の可能性もあり，今後の 検討が待たれる。しかし，巨大肝癌でTAEにより著明 に看痬が縮小し，肝切除可能となり 5 年以上無再発の 症例むあり ${ }^{21)}$, 症例によっては術前 TAEの有效性が
期待できるものと思われる。

次に術前 TAEによる肝機能への影響をみるために TAE 前と手術前の値を比較したが TAEにより影響 をらけた臨床検查値はアルブミンコリンエステラー ゼ,プロトロンビン時間, ZTT, $\gamma$-ダロブリンであっ た. アルブミン、コリンエステラーゼ，プロトロンビ ン時間は蛋白合成能を反映しており，肝切除に際して はこれら臨床検査値の低下は大いに問題になるところ ではあるが, 肝切除可能な症例は肝硬変合併例です比 較的肝予備能が保たれている症例が多く，耐術可能で あった。しかしわわわれは TAE 後 1 力月を目度に肝 切除を行らことを原則としているが，TAE後の肝機 能低下のため耐術の critical point ぎりぎりの症例も 多く，切除範囲の縮小を余儀なくされることや，手術 までの期間を延長せざるを得ないことがあり，問題点 である. 自験例での手術死は69例中 4 例 (5.8\%) であ り, 術前 TAE 非施行肝切除例の山梨医科大学第 1 外 科 $9.5 \%$, 兵庫医科大学第 1 外科 $6.5 \%$ と比較しても差 はない?.

TAEの合併症の一つとして壊死性胆票炎がある。 胆票を有する症例では大なり小なり必発し，肝十二指 腸勒帯に及心゙炎症性変化は術中の肝門部処理を困難に することが多い. ZTT, $\gamma$ ・グロブリンの上昇はこれら の炎症性変化を反映しているものと考えられる。

術前無治療肝切除症例の予後因子については幾多の 文献があるが, 術前 TAE 併用肝切除 HCC の予後因 子についての報告は少ない，自験例の検討では，予後 を左右すると考えられる関連因子14項目を選び, 各々 に条件を設定し推定生存率を出し, Logrank 法にて有 意差検定を行った。有意差が認められたのは，(1) vp の有無, (2) 手術根治度, (3) 術中出血量 $1,000 \mathrm{~g}$ 以上 と以下の 3 項目であった．有意の傾向にあったのは,

（1）Stage 分類，(2）主腫瘍内残存癌の有無であった。 その他の 9 項目，（1）年龄，（2）性，（3）畽場占拠部 位,（4）非癌部肝組織型，（5）肝内転移(IM）の有無, （6）被膜形成の有無，(7)肝切離面における癌浸潤 (tw)の有無，（8）切除域，（9）手術時間( 5 時間以上, 以下）は有意差を認めなかった。

自験例での検討で最も予後を左右する因子は顕微鏡 的門脈内腫湯塞栓 (vp)の有無であった.この vpの有 無が予後及び再発と関連があることを最初に記載した のは岡崎ら ${ }^{18)}$ である. その後, 術前無治療肝切除症例や TAEの予後を左右する最大の因子であるとの報告は 多数認められる ${ }^{19224}$. 自験例で, 術前 TAE 併用肝切除 
のなか, vp (十) 症例と vp (一) 症例の予後を比較し たところ，3 生率 $32.6 \%, 80.5 \% ， 5$ 生率 $0 \%, 65.8 \%$ であり，有意確率は $0.0017 て ゙$ 両者間に著しい有意差が 認められた。 $\mathrm{vp}(+)$ 症例はすべて 4 年以内に死亡し， 13例中 3 例の 久が再発生存中であり, 現在無再発の 3 例も術後最長 1 年 2 カ月しか経過していない。

このよらに術前 TAEを行っても, vp は壊死に陥ら ず, 術後，高率に再発し死亡している，むし vp に有効 な他の治療法が開発されるならば，術前 TAE との併 用により肝切除症例の予後向上につながるものと思わ れる。

有意差を認めた手術根治度については絶対的治瘾切 除, 相対的治瘾切除, 相対的非治瘾切除, 絶対的非治 瘾切除で, 各症例の 5 生率はそれぞれ71.4\%, 52.6\%, 45.3\%，0\%であり, 絶対的非治瘾切除の予後は極端 に悪かった。しかし，両葉に多数の肝内転移巣をるつ 若年者の大型肝癌症例に対し, 社会的適応下に主腫瘍 及びその周囲の転移巣を切除し, 残存小病巣に対して 術後も TAEを行い 3 年以上の生存が得られた症例も あるので, 癌病巣の減量手術後, 残存病巣に対し術後 TAE や化学療法などの集学的治療を行い延命効果を はかることも必要と思われる。

術中出血量を $1,000 \mathrm{~g}$ 末満と $1,000 \mathrm{~g}$ 以上で分けて検 討したところ， 5 生率は各々 $60.8 \% ， 43.8 \%$ と両者間 に有意差を認めたが, 出血量が多かった症例には進行 した HCC の頻度が高かったこともその一因と考えら れる。

有意の傾向を認めたものの 1 つに肝癌取扱い規約 Stage 分類がある. 自験例では Stage が進むにつれて 生存率の低下がみられた。しかし，最も早期の HCC と されている Stage I 症例においても50\%に再発を認 め, この 9 例中 5 例が 2 年以内に再発している. HCC の特殊性からして残存肝に癌発生の母地が残ってお ク，癌化の可能性も否定できないが HCC に対しては も5少し綿密な分類法が必要と思われる。

次に TAE 後主腫場内に癌残存の有無あるいは量的 差により，生存率に有意傾向が認められたが，完全壊 死症例の多くは $30 \mathrm{~mm}$ 径末満の小腫瘍であったことか らも，進行していないHCCに対する TAEの効果の 一面をとらえたと考光ている.

有意差を認めなかったもののらち, 非癌部肝組織型 について，松本ら ${ }^{22)}$ は，肝硬变合併例之非合併例 HCC の肝切除成績は各々 1 生率 $67.9 \%, 65.5 \%, 3$ 生率 $19.2 \%, 46.5 \%, 5$ 生率 $18.0 \%, 45.2 \%$ と前者の予後
が悪いと述べており，諸家の報告例も同様である，自 験例では非癌部肝組織型を肝硬変, 慢性活動性肝炎, 慢性非活動性肝炎に分け，生存率を検討したが有意差 を認めなかった。しかし，5年以降の成績をみると肝 硬変症例の推定生存率は低い上うであり, 肝硬変の自 然経過や予後と関係があるように思われる。

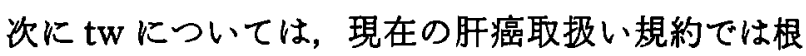
治度判定上大きな比重を占めているが, 自験例での tw の有無と予後との間には有意差は認めなかった. 即ち, $\mathrm{tw}(+)$ 13例中, 単発腫場で vp (一) の症例が 5 例あ り,このらち 3 例は再発を認めなかったが, 再発した 2 例のなか, 1 例が術後 4 年を経過して再発し， 1 例 が 1 年以内に再発している. HCCでは, 肝硬变を合併 する頻度が高率であり，肉眼的に腫場から $1 \mathrm{~cm}$ 離して 切離することは必ずしる容易ではなく，また twと予 後との相関は低いとの報告 ${ }^{14)}$ す多いので, tw 因子によ る根治判定基準は再考されるべきと考光る.

肝内転移 (IM) の有無が予後に影響を与えるとの瀬 川ら 23)の報告もあるが，幕内ら ${ }^{14)}$ は両者間に有意差を 認めていない，自験例では IM (十) 症例と IM (-) 症例の生存率を比較したが，両者間に有意差は認めな かった。しかし，3生率と 5 生率間に差がみられてい る. IM (十)のなか, vp (十)症例は 8 例あり，また， vp $(+)$ 症例はすへて 4 年以内に死亡しているので, この両者間の差はvp $(+)$ が関係しているすのと思わ れる.

予後に同時に影響を及ぼす要因を検索するためにク ラスター分析による多変量解析を行ったが, 各クラス ター 1 - 4 の $50 \%$ 生存率は各々 2 年, 3 年 6 力月, 5 年 1 力月, 6 年 9 力月であった。 $50 \%$ 生存率が 5 年以 上に及ぶ症例群，すなわちクラスター3およびクラス ター4に含まれるものは vp (一), 主腫腸径 $30 \mathrm{~mm}$ 以 下, Stage III 以下の65歳以下の症例であり，換言すれ ばvp (一) かつ主腫瘍径 $30 \mathrm{~mm}$ 以下の単発あるいは多 発でも一葉に限局した症例であった。 クラスター1の Stage IV のものはvp (一), 主腫煬径 $30 \mathrm{~mm}$ 以下でも 3 年生存率 $0 \%$ であり，また, vp $(+)$ 症例は, 主腫 湟径 $46 \mathrm{~mm}$ 以下であすべて同様であった。すなわち, $\mathrm{vp}(+)$ の症例は腫湯径をとわず予後が悪いのに対し， 65歳以下で $\mathrm{vp}(-)$, かつ腫瘍径 $30 \mathrm{~mm}$ 以下の症例は単 発または多発です一葉に限局しておれば予後は良好と いらことになる。

以上, HCC の予後を左右する各因子について検討を 加えたが個々の因子のみでは予後判断は困難かつ, あ 
いまいであり，治療上です問題を残しやすいが，今回 の分析のように各因子を総合的に検討したことにより 極めて正確な予後判断が得られたすのと思われる。従 来，このような判定方式を採用した報告は見られない ので，今後は多変量解析を取り入れた総合的な検討が 必要であると思われた。

\section{結 論}

1. 術前 TAEの最大の利点は, Lipiodol-TAE 後 CT 像による微小娘結節の発見にあると考える。

2. 術前TAEにて, HCC が完全壊死に陷った症例 と, 腫瘍が残存していた症例間の再発率及び推定生存 率には有意差は認められなかった，TAE 併用肝切除 症例の再発率は $58.5 \%$ で, 諸家の術前無治療肝切除症 例の再発率報告とほぼ同様であった。

3. $\mathrm{TAE}$ 前後でフルブミン, コリンェステラーゼ, プロトロンビン時間が有意に低下した。このことは肝 切除の適応決定の問題点となりらる。

4. TAE 併用肝切除症例では, vpの有無, 手術根治 度, 出血量 $(1,000 \mathrm{~g}$ 以上, 以下) が生存率に有意に関 係していた。

5. クラスター分析による多変量解析にて, vp (-) で主腫瘍径 $30 \mathrm{~mm}$ 以下の単発病変もしくは単葉に存在 する多発病変で65歳以下の症例は, TAE 併用肝切除 にて 5 年以上生存する可能性が50\%以上であった，術 前 TAE はvp $(+)$ 症例には効果はみられず予後は腫 瘍径と関係なく不良であった。

稿を終えるにあたり，統計に関して，全面的に御協力いた だいた塩野義製薬解析センター, 田崎武信, 塩津秀夫両氏に 潹く感謝の意を捧げます。

\section{文献}

1) Makuuchi $M$, Hasegawa $H$, Yamazaki $S$ : Ultrasonically guided subsegmentectomy. Surg Gynecol Obstet 161:346-350, 1985

2）日本肝癌研究会編：原発性肝癌に関する追跡調査 一第 7 報一，肝䁍 $27: 1161-1169,1986$

3) Warren EE, Laffer UT, Block GE, et al : Enhanced survival of patient with colon and rectal cancer is based upon wide anatomic resection. Ann Surg 190 : 350-360, 1979

4）厚生省がん研究助成金計画研究第15班：肝癌に対 する集学的治療一Embolizationを併用した肝切 除の検討一, 肝胆膵 $5: 1195-1200,1982$

5）岡村 純, 門田守人, 堀川真一他：肝癌に対する化 学塞栓療法一壊死効果の機作と手術適応につい $\tau$, 癌と化療 $10: 340-350,1983$
6）藤原史郎，岡本英三，山中若樹他：肝切除療法を軸 とした肝癌集学的治療の意義, 日外会誌 91 ： 1375-1377, 1990

7）梅下浩司，岡村 純，門田守人他：肝細胞癌の予後 はどのよらに変わっているか, 消化器外科 8 : 1875-1880, 1985

8）岡崎正敏：進行肝癌に対する動脈塞栓術一出血の コントロールを含を一, 画像診断 $10 ： 1047$ $-1053,1990$

9) Yamada $R$, Sato $M$, Kawabata $M$, et al: Hepatic artery embolization in 120 patients with unresectable hepatoma. Radiology 148: 397-401, 1983

10）大藤正雄, 杉浦信之, 江原正明他：畽湯内アルコー ル注入療法ならびに放射線療法による肝癌の治 療, 癌之化療 $13: 1625-1634,1986$

11) Kaplan E, Meier P: Nonparametric estimation from incomplete observations. J Am State Assoc 53: 457-481, 1959

12）柳井晴夫, 高木廣文 編著 : 多变量解析ハンドブッ ク. 現代数学社, $\mathrm{p} 224-242,1986$

13）幕内雅敏, 高山忠利, 山崎 晋他：肝硬変合併肝癌 治療の Strategy, 外科診療 $29: 1530-1536,1987$

14）高山忠利, 幕内正敏, 小西宗明他：肝癌の相対非治 垫切除一成樍とその問題点一, 臨外 43：1317 $-1324,1988$

15) Takayasu K, Muramatsu $Y$, Moriyama $N$, et al: Clinical and radiologic assessments of the results of hepatectomy for small hepatocellular carcinoma and therapeutic arterial embolization for post operative recurrence. Cancer 64 : 1848-1852, 1989

16）黑田雄志, 岡崎正敏, 小野広幸他：肝細胞癌の術後 残肝再発に関する臨床病理学的検討，日消外会誌 $22: 2256-2264,1989$

17) Anthony P, Vogel C, Barker L: Liver cell dysplasia ; a premalignant condition. J Clin Pathol 26 : 217-223, 1973

18）岡崎正敏, 森山紀之, 山田達哉：肝癌の血管造影所 見の意義一門脈所見から見た手術適応ならびに予 後との関係一, 日消病会誌 $77: 758-767,1980$

19）竜 宗正, 山本義一, 山本 宏他：肝動脈塞栓衍併 用肝切除例の検討，日消外会誌 $18: 60-65,1985$

20）東原秀行, 岡崎正敏, 小金丸史隆：肝細胞癌画像診 断の問題点一肝切除標本との対比一, 腹部画像診 断 $7: 208-215,1987$ 
21）橋本幹稔，岡崎正敏，小金丸忠隆他：術前肝動脈塞 拴術により肝切除が容易となった巨大肝細胞癌 2 例の治療経験, 臨放線 $33: 621-624,1988$

22）松本由朗, 山本正之, 菅原克彦他：肝癌の手術適応 と予後, 臨と研 $62: 102-109,1985$

23）瀬川 徹, 井沢邦英, 松元定次他：原発性肝細胞癌 に怙ける予後規定因子，日消外会誌 23：1071 $-1077,1990$

24）山崎 晋, 長谷川博, 幕内正敏 : 細小肝癌の臨床病 理学的分析とそれにもとずく新しい概念の切除法
-27切除例の検討一, 肝荿 $22: 1714-1724,1981$

25）日本肝癌研究会編：臨床·病理. 原発性肝癌取扱い, 規約, 金原出版, 1987

26) Breiman L, Friedman JH, Olshen RA, et al: Regression Trees. Classification and Regression Trees. Chapter 8: Wadworth, New York 1984, p216-265

27) Segal MR: Regression trees for censored data. Biometrics $44: 35-47,1988$

\title{
STUDIES ON THE EFFECTS OF TAE BEFORE HEPATECTOMY AGAINST HCC
}

\author{
Atsuo KATAOKA, Hirotsune IGIMI and Hidehiko SHIMURA \\ First Department of Surgery, Fukuoka University School of Medicine \\ Masatoshi OKAZAKI \\ Department of Radiology, Fukuoka University School of Medicine
}

In 65 patients undergoing hepatectomy for hepatocellular carcinoma (HCC) after transcatheter arterial embolization (TAE), the value of preoperative TAE and effective factors possibly influencing upon prognosis were studied. The best advantage of preoperative lipiodol-TAE for HCC was a development on the CT findings of tiny daughter nodules. Whereas, side effects of preoperative TAE were significant decreases of serum albumin and choline-esterase values and a significant prolongation of prothrombin time. Fourteen factors which might affect the prognosis in this treatment were selected and statistically analyzed. Significant difference was noted in 3 factors, namely, the existence of histological portal tumor thrombus, operative curability, and bleeding volume during surgery. From the Claster multi-parametric analysis, more than $50 \%$ of survival rate after operation depended upon the following factors; absence of histological portal tumor thrombus, solitary or multiple tumors with diameters of less than $30 \mathrm{~mm}$ in a single lobe of the liver, and the age of under 65 years old. 